\title{
Assessment of vitamin D-binding protein (DBP) gene polymorphisms and their correlation with multiple sclerosis: a case- control study in a sample of the Syrian population
}

Bushra Alhomsi ${ }^{1}$, Ghalia Aboualchamat ${ }^{1 *}$ (i) and Imad Alkadi ${ }^{2}$

\begin{abstract}
Background: Vitamin D deficiency is a major health concern as it increases the risk of developing many serious diseases. Recently, the correlation between vitamin D deficiency and multiple sclerosis (MS) is a matter of serious debate. In this case-control study, we aimed to assess the correlation between genetic changes in the vitamin Dbinding protein (DBP) gene and their consequence on MS patients. Our sample study consisted of 110 individuals; 40 patients with MS as cases and 70 healthy controls. Vitamin D levels were determined by immunofluorescence assay, and polymorphisms at rs7041 (c.1296 T > G p.Asp416Glu) and rs4588 (c.1307C > A p.Thr420Lys) of the DBP gene were genotyped using PCR/RFLP method for all cases and controls.

Results: Our results showed that genotype frequencies were consistent with Hardy-Weinberg equilibrium. A significant association was found in rs7041 (c.1296Th) homozygous wild-type, and the odds ratio was < 1 suggesting a protective role against developing MS (OR; $0.03, p=0.0002$ ) whereas the $c .1296 \mathrm{GG}$ genotype was significantly correlated with an increased risk for MS by 6 folds (OR: 6.0000, $p<0.0001$ ). No significant association was noted at rs4588 and MS occurrence. In addition, our compound genotyping results revealed that haplotypes 1S-1S are 6 times more likely to develop MS, whereas haplotypes $1 \mathrm{~F}-1 \mathrm{~F}$ had a more protective role in MS patients (OR: $0.063, p=0.06$.), respectively. The risk of vitamin $D$ insufficiency in patients was greater by 14 folds compared to controls (OR: 14.05, $p=0.0128$ ). Furthermore, the c.1296GG genotype was associated significantly by more than 4 times with insufficient levels of vitamin $D$ and by 7 folds with vitamin deficiency.

Conclusions: We conclude that polymorphisms in the DBP gene could have independent effects on the risk of developing multiple sclerosis. The homozygous recessive genotype at rs7041 was associated with insufficient levels of vitamin D and with the risk of MS emergence.
\end{abstract}

Keywords: Multiple sclerosis, Vitamin D deficiency, Polymorphism, Vitamin D-binding protein gene DBP

\footnotetext{
* Correspondence: dr.ghalia-aboualchamat@hotmail.com

'Department of Biology, Faculty of Science, Damascus University, Damascus,

Syria

Full list of author information is available at the end of the article
}

(๑) The Author(s). 2020 Open Access This article is licensed under a Creative Commons Attribution 4.0 International License, which permits use, sharing, adaptation, distribution and reproduction in any medium or format, as long as you give appropriate credit to the original author(s) and the source, provide a link to the Creative Commons licence, and indicate if changes were made. The images or other third party material in this article are included in the article's Creative Commons licence, unless indicated otherwise in a credit line to the material. If material is not included in the article's Creative Commons licence and your intended use is not permitted by statutory regulation or exceeds the permitted use, you will need to obtain permission directly from the copyright holder. To view a copy of this licence, visit http://creativecommons.org/licenses/by/4.0/. 


\section{Background}

Vitamin D deficiency represents a global health problem for all age groups [1-3]. Several studies have demonstrated a correlation between vitamin D deficiency and increased risk of many diseases such as cancer, autoimmune diseases as type 1 diabetes, rheumatoid arthritis, and sclerosis [4-7]. Recent studies proposed the high prevalence of vitamin D deficiency, particularly amongst Arabs and Middle Eastern countries, to the presence of important responsible factors, as the genetic variations $[8,9]$. The vitamin D-binding protein $(D B P)$ gene (ID: 2638) plays an important role in the transfer and metabolism of vitamin D and its stimulation, so it is considered an essential component for maintaining the natural balance of this vitamin in the body. It is well known that the $D B P$ gene has many polymorphic regions amongst humans $[10,11]$. Genetic variants in this gene affect the transfer of vitamin $\mathrm{D}$ in the body, leading to its deficiency [12]. The $D B P$ gene has three common alleles, $1 \mathrm{~F}, 1 \mathrm{~S}$, and 2 , regarding the combination of the two single nucleotide polymorphism (SNPs), rs7041 (c.1296 T > G p.Asp416Glu), and rs4588 (c.1307C > $A$ p.Thr420Lys) [13]. These two SNPs result in various protein isoforms and have a different binding affinity for vitamin D $[14,15]$. Several studies argued the effect of genetic changes in the $D B P$ gene and the risk of developing multiple sclerosis (MS) [16-18]. MS (OMIM 126200) is a neurological autoimmune chronic disease [19]. Recent studies suggest an increasing incidence of MS in developing countries [20]. It constitutes one of the causes of early disability and unemployment as well as a great economic burden imposed on society [21]. In Syria, multiple sclerosis deaths reached $0.01 \%$ of total deaths, ranking Syria to be number 99 in the world of MS death rates [22]. No previous studies have been conducted to determine the relationship between $D B P$ gene common variations and the risk of MS nor its consequence on vitamin D concentration. Therefore, we aimed in this study to investigate whether the common genetic variants rs7041 and rs 4588 in the DBP gene have an influence on MS development and vitamin D levels in a sample of Syrian population.

\section{Methods}

\section{Criteria and study samples}

Forty patients with multiple sclerosis, receiving their monthly medication from Ibn al Nafise hospital, were recruited as cases, while 70 healthy individuals randomly selected with no family history, contributed as a control group. Taking any vitamin supplements was considered as exclusion criteria. All cases and controls were aware of the study, and written consents were taken from all participants. Peripheral blood samples from cases and control groups were collected; the blood was drawn for each individual into two separate tubes, clot activator vacutainer for vitamin concentration analysis and tubes containing 0.1\% EDTA tubes for molecular analysis.

\section{Serum 25-hydroxyvitamin D concentration analysis}

Tubes containing the blood from cases and controls were centrifuged immediately after drawn at $4000 \mathrm{rpm}$, and serums were stored in the dark at $-20^{\circ} \mathrm{C}$ until analyzing. Measurement analysis was performed at $\mathrm{Al}-$ Mouwasat University Hospital, based on immunofluorescence assay principle by $i$-Chroma analyzer using Ichroma ${ }^{\mathrm{Tm}}$ Vitamin D kit, according to the manufacturer's protocol. Vitamin D deficiency was defined as serum $25(\mathrm{OH}) \mathrm{D} 3<10 \mathrm{ng} / \mathrm{mL}$, insufficient as $<30 \mathrm{ng} /$ $\mathrm{mL}$ and sufficient $>30 \mathrm{ng} / \mathrm{mL}$ [23].

\section{Genomic DNA isolation and genotyping}

Genomic DNA was isolated from peripheral blood from cases and controls using Vivantis Technologies, GF-1, Blood DNA Extraction Kit, Malaysia, as instructed by the manufacturer. The amplification of $482 \mathrm{bp}$ PCR product around the two variants studied ( $r s 7041, r s 4588$ ) at the $D B P$ gene was accomplished using the following pair of primers: F. Primer (5'AAATAATGAGCAAATGAAAGAAGAC3') R. Primer (5' CAATAACAGGAA AGAAATGAGTAGA3') [24]. PCR reactions contained $10 \mu \mathrm{M}$ of each primer, $12.5 \mu \mathrm{l}$ of OnePCR $^{\mathrm{m} m}$ Mix (2X) (GeneDirex, Inc), $6.5 \mu \mathrm{l}$ of nuclease-free water, and $3 \mu \mathrm{l}$ of genomic DNA. A nuclease-free water was run with each PCR experiment for contamination detection (negative control). PCR reactions were done using the Eppendorf Master Cycler. The amplified products were electrophoresed in $2 \%$ agarose gel containing ethidium bromide, visualized and photographed using a UV transilluminator (Olymbus). Each 482 bp PCR fragment was digested twice for all cases and controls using HaeIII restriction enzyme (Thermo Scientific, $2000 \mathrm{U}$ ) to determine genotypes of the $c .1296 T>G$ variant ( $r s 7041$ ), and StyI restriction enzyme (Thermo Scientific, $2500 \mathrm{U}$ ) to define $c .1307 C>A$ genotypes ( $r$ 4588) according to manufacturer's instructions. Fragments were analyzed by $2 \%$ agarose gel electrophoresis using 100 bp DNA Ladder (Thermo Scientific, GeneRuler).

\section{Statistical analysis}

The statistical analyses were performed using MedCalc ${ }^{\circ}$ (Version 14.8.1) statistical program. The qualitative variables were given as frequency and percentage. Chisquare $\left(\chi^{2}\right)$ test was used to identify deviations from the Hardy-Weinberg equilibrium amongst all cases and controls. Mann-Whitney test was used to calculate the differences between averages of the two groups. Fisher's exact test was used to assay the relationship between qualitative variables. A significance level of $p<0.05$ was considered statistically significant. The odd's ratio (OR) 
was used to estimate the association between a specific genotype and the risk of MS or between vitamin D concentration levels and MS, using logistic regression analysis.

\section{Results}

Our sample study consisted of 110 individuals; 40 patients with multiple sclerosis and 70 healthy controls. Patients were 16 males (40\%) and 24 females $(60 \%)$, while controls were 21 males (30\%) and 49 females (70\%). All ages ranged from 17 to 57 years old. Genotyping of the two $r s 7041$ and $r s 4588$ SNPs were successfully achieved for all controls and cases (Fig. 1).

Genotype frequencies at $r s 7041$ and rs4588 were consistent with Hardy-Weinberg equilibrium $(P$ values $=$ 0.76 and 0.55 , respectively). The most frequent genotype amongst controls was the heterozygous TG genotype (51.4\%), while the GG homozygous genotype was mostly identified between MS patients (60\%) and no wild type TT was detected among them. Furthermore, our data showed that the wild type CC was frequently detected amongst patients and controls ( $75 \%$ and $62.9 \%$, respectively), and the homozygous genotype AA was rare in controls and was not detected at all amongst MS patients (Table 1). The haplotype $1 \mathrm{~S}$ was detected at a high frequency in patients with MS (80\%). In addition, the lowest distribution of haplotypes was haplotype 2 among patients (12.5\%) and controls (20\%) (Table 2). Association analysis of different genetic models between cases and controls at rs7041 has shown significant differences $(p<0.05)$ for all genetic models, except at overdominant (TT + GG) vs. TG, suggesting a weak impact of this model on MS. However, no significant differences were found at $r s 4588$ in any of the genetic models studied (Table 3).

Our data indicated a significant correlation in serum vitamin $\mathrm{D}$ levels between the two studied groups $p<$ 0.05 . The association between MS and vitamin D deficiency (less than $10 \mathrm{ng} / \mathrm{mL}$ ) was significant, the odds ratio was $>1$ implying that there is an increased risk by more than 4 folds (OR 4.93, 95\% CI 1.5705 to $15.4826, p$ $=0.005)$. On the other hand, a significant correlation was found between insufficient vitamin D concentrations (less than $30 \mathrm{ng} / \mathrm{mL}$ ). The risk of vitamin D insufficiency in patients was greater by 14 folds compared to controls (OR: $14.05,95 \%$ CI: 0.8012 to $246.6673, p=0.0128)$. No patients had adequate or sufficient (more than $30 \mathrm{ng} /$ $\mathrm{mL}$ ) amount of vitamin D levels (Table 4).

Furthermore, our results showed a significant association at rs7041 homozygous genotypes; the odds ratio at homozygous wild-type TT was $<1$ suggesting a protective role against MS (OR; 0.03, 95\% CI: 0.0017 to 0.5183 , $p=0.0002)$. While there was an increased risk for MS at GG genotype by 6 folds (OR: 6.00, 95\% CI: 2.5337 to $14.2084, p<0.0001)$. However, no significant correlation was found between MS and heterozygous genotype TG (OR: $0.6296,95 \%$ CI: 0.2865 to $1.3836, p=0.25$ ). On the other hand, our data revealed no significant association between SNPs at $r s 4588$ and MS occurrence. As for the association of MS disease and compound genotypes, we found a significant correlation with haplotypes $1 \mathrm{~F}-1 \mathrm{~F}(p$ $=0.059)$, and $1 \mathrm{~S}-1 \mathrm{~S}(p=0.0001)$, while no considerable correlation was found with the other compound genotypes (1F-1S, IF-2, 1S-2 and 2-2) (Table 2).

Our data revealed that only genotypes containing the GG variant of the rs7041 were associated significantly with insufficient levels of vitamin D by more than 4

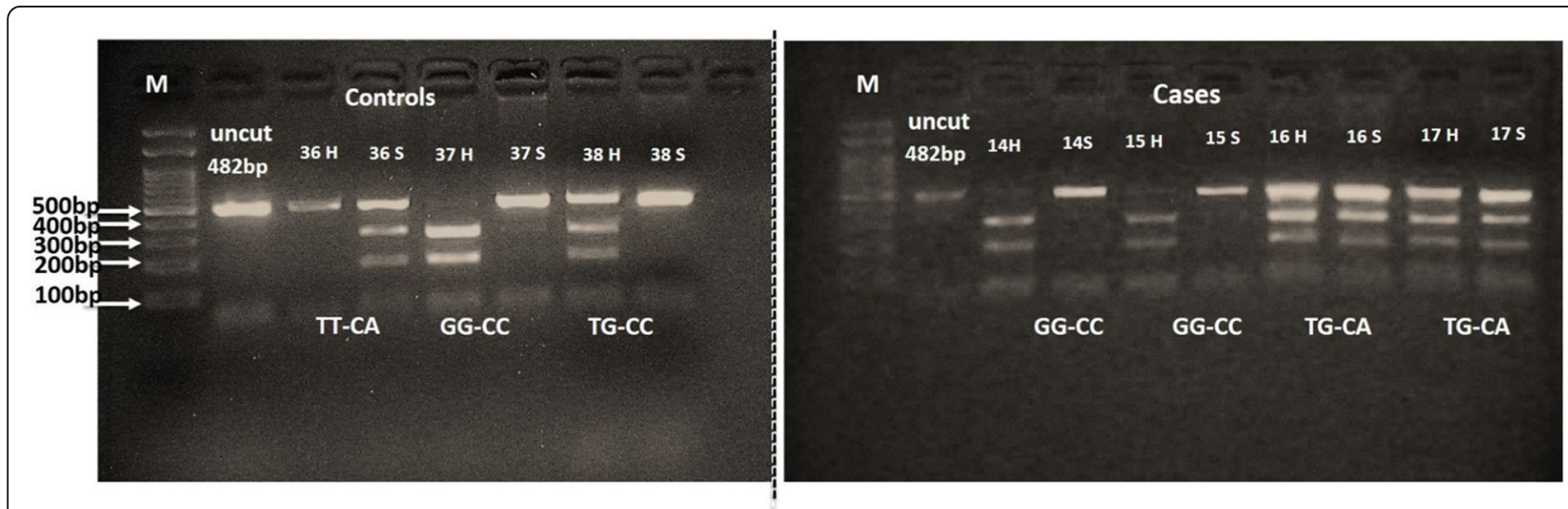

Fig. 1 Two separate PCR-RFLP 2\%gel electrophoresis results for cases and controls. M: 100 bp molecular marker, 482 bp represents the uncut PCR product. Each case or control has two results depending on the different restriction enzymes used; $\mathbf{H}$ : Haell that cuts at 1S polymorphic site thus: homozygous wild type $\Pi$ gets no cut fragments as in sample 36; while homozygous GG genotype gets two fragments (297, 185 bp) as in samples 37, 14, 15, whereas heterozygous TG gets three fragments $(482,297,185)$ as in samples 38, 16, and 17. S: Styl which cleaves at 2 polymorphic sites as a result homozygous wild type CC gets no cut fragments as in samples $37,38,14$, and 15 . While heterozygous CA gets three fragments (482,308, and $174 \mathrm{bp})$ as in samples 36,16 , and 17 
Table 1 Distribution of DBP gene genotypes variations

\begin{tabular}{|c|c|c|c|c|c|c|c|c|c|c|}
\hline & \multicolumn{5}{|l|}{ Genotypes } & \multirow{2}{*}{\multicolumn{5}{|c|}{ rs4588 }} \\
\hline & \multicolumn{5}{|l|}{ rs7041 } & & & & & \\
\hline & $T$ & G & $\pi$ & $\mathrm{TG}$ & GG & $\mathrm{C}$ & A & CC & CA & AA \\
\hline Control $(n=70)$ & 76 (54.2\%) & $64(45.7 \%)$ & $20(28.6 \%)$ & $36(51.4 \%)$ & $14(20 \%)$ & $112(80 \%)$ & $28(20 \%)$ & 44 (62.9\%) & $24(34.3 \%)$ & $2(2.9 \%)$ \\
\hline $\mathrm{MS}(n=40)$ & $16(20 \%)$ & $64(80 \%)$ & $0(0 \%)$ & $16(40 \%)$ & $24(60 \%)$ & $70(87.5 \%)$ & $10(25 \%)$ & 30 (75\%) & $10(25 \%)$ & $0(0 \%)$ \\
\hline$P$ value & $<0.0001^{*}$ & $<0.0001^{*}$ & $0.0002^{*}$ & 0.250 & $<0.0001^{*}$ & 0.282 & 0.193 & 0.193 & 0.312 & 0.282 \\
\hline
\end{tabular}

${ }^{*}$ Statistically significant associations $(p<0.05)$

times increased risk (OR: 4.9, 95\% CI: 2.0634 to 11.7720 , $p=0.0003$ ) and with deficiency by 7 folds. Likewise, haplotype analysis of $r s 7041$ and $r s 4588$ showed that haplotypes (1S-1S) were associated with vitamin D insufficiency ( $p=0.0002)$ by more than 15 times increased risk. By contrast, haplotypes $(1 \mathrm{~F}-1 \mathrm{~F})$ were associated with decreased risk of insufficient levels of vitamin D ( $p=0.012)$ odds ratio $<1$ suggesting a protective role against MS. No significant association was found for the other different genotypes.

\section{Discussion}

Multiple sclerosis (MS) is an inflammatory autoimmune disease affecting young adults, initiated by attacking the immune system the protective sheath (myelin) that covers the nerve fibers and preventing the dispersion of electrical charges, causing permanent damage to the nerves and leading to disability [25]. The cause of MS is generally unknown; however, many factors contribute to the development of this disease such as an individual's genetic makeup and environmental risk factors as inadequate vitamin D levels which may contribute to the severity and long-term progression of the disease [26, 27]. Our present study showed that MS patients are 4 times more likely to suffer from vitamin D deficiency and have 14 times increased risk of having insufficient vitamin $\mathrm{D}$ levels, these findings are compatible with various studies which indicated that vitamin D levels are lower in MS patients compared to healthy controls [28, 29]

Vitamin D plays an indirect role in multiple sclerosis through stimulating cytokines that considered a key mediator in most of the body's immune infections. Studies have found that $60 \%$ of patients with MS suffer from vitamin $\mathrm{D}$ deficiency, which reduces the secretion of cytokines, affecting in turn, the immune system and leads to a high rate of infections $[30,31]$. Therefore, the consideration of vitamin $\mathrm{D}$ levels in multiple sclerosis patients is extremely important for early compensatory treatment. In addition, previous interventional studies have recommended that maintaining optimal vitamin $\mathrm{D}$ levels in healthy individuals could decrease the risk of developing MS [26, 32]. Our data showed no significant association with variants at $r s 4588$ in the DBP gene. While, a significant correlation was found for rs7041 homozygous genotypes; the TT wild type genotype was not found amongst patients, suggesting that this particular genotype has a low risk of developing MS or having a protective role against having the disease. In contrast, our results revealed that the GG genotypes are more likely to develop MS by more than 6 times compared to controls and have an increased risk for suffering from insufficient levels of vitamin $\mathrm{D}$ or deficiency by more

Table 2 Distribution of the compound genotypes for the two DBP gene variations

\begin{tabular}{llllll}
\hline Haplotypes name & Combination of rs7041 and rs4588 genotypes & Control, $n(\%)$ & MS, $n(\%)$ & $P$ value & Odds ratio \\
\hline 1F-1F & T CC & $11(15.7 \%)$ & $0(0 \%)$ & $0.059^{*}$ & 0.063 \\
1F-1S & TG CC & $19(27.1 \%)$ & $6(15 \%)$ & 0.149 & 0.473 \\
1F-2 & T CA & $7(10 \%)$ & $0(0 \%)$ & 0.125 & 0.104 \\
$1 S-1 S$ & GG CC & $14(20 \%)$ & $24(60 \%)$ & $0.0001^{*}$ & 6.000 \\
1 S-2 & TG CA & $17(24.3 \%)$ & $10(25 \%)$ & 0.93 & 1.039 \\
2-2 & T AA & $2(2.9 \%)$ & $0(0 \%)$ & 0.487 & 0.338 \\
1F & T-C & $65(46.4 \%)$ & $16(20 \%)$ & $0.00008^{*}$ & 0.157 \\
1S & G-C & $64(45.7 \%)$ & $64(80 \%)$ & $0.000001^{*}$ & 4.75 \\
2 & T-A & $28(20 \%)$ & $10(12.5 \%)$ & 0.193 & 0.564 \\
\hline
\end{tabular}

*Statistically significant associations $(P<0.05)$ 
Table 3 Association analysis results for rs7041 and rs4588 genotypes under different genetic models

\begin{tabular}{|c|c|c|}
\hline \multicolumn{3}{|l|}{ rs7041 (c.1296 T > G) } \\
\hline Genetic model & OR $(95 \% \mathrm{Cl})$ & $p$ value \\
\hline Dominant TT vs. (TG+ GG) & $0.03(0.001$ to 0.51$)$ & $p=0.01^{*}$ \\
\hline Recessive $(T T+T G)$ vs. GG & $6.00(2.53$ to 14.20$)$ & $p=0.0001^{*}$ \\
\hline Over dominant $(T T+G G)$ vs. TG & $0.62(0.286$ to 1.38$)$ & $p=0.24$ \\
\hline Homozygous codominant TT vs. GG & 69.27 ( 3.89 to 1233.65$)$ & $p=0.0039^{*}$ \\
\hline Heterozygous codominant (TT vs. TG) & 18.53 (1.056 to 325.28$)$ & $p=0.045^{*}$ \\
\hline Allele contrast (T vs. G) & 2.80 (1.398 to 5.604) & $p=0.0036^{*}$ \\
\hline \multicolumn{3}{|l|}{ rs4588 (c.1307C > A) } \\
\hline Genetic model & OR $(95 \% \mathrm{Cl})$ & $p$ value \\
\hline Dominant CC vs. $(C A+A A)$ & 1.77 (0.74 to 4.20$)$ & $p=0.194$ \\
\hline Recessive $(C C+C A)$ vs. $A A$ & 0.33 (0.015 to 7.223$)$ & $p=0.4877$ \\
\hline Over dominant $(C C+A A)$ vs. $C A$ & $0.63(0.267$ to 1.52$)$ & $p=0.312$ \\
\hline Homozygous codominant (CC vs. AA) & 0.29 (0.013 to 6.29) & $p=0.431$ \\
\hline Heterozygous codominant (CC vs. CA) & $0.61(0.255$ to 1.46$)$ & $p=0.268$ \\
\hline Allele contrast (C vs. A) & 0.65 (0.285 to 1.4955$)$ & $p=0.314$ \\
\hline
\end{tabular}

*Statistically significant associations $(p<0.05)$

than 4 times compared to controls. Moreover, our genetic models' analysis results showed a significant association under three models (dominant, recessive, and codominant) $\mathrm{OR}>1$, the strongest impact was for homozygous codominant which may emphasize the potential role of GG genotypes as a risk factor for developing MS. These findings come in agreement with previous studies which showed that a decrease in the concentration of vitamin D in patients with MS was associated with the presence of genetic changes, most notably at rs7041 in the $D B P$ gene $[16,33]$ and can be explained that genetic polymorphisms cause low concentration of vitamin D levels and increase susceptibility to develop MS [34-36]. Our data were also consistent with previous studies that highlighted the susceptibility of the GG genotype and its correlation with many diseases like colorectal and lung cancers [37] as well as coronary artery disease (CAD), food allergy and also was associated significantly with a decrease in circulating levels of vitamin D [38-40]. However, other investigators found no significant association between $D B P$ gene polymorphisms and MS disease risk [18, 41]. Moreover, a study led by Agliardi et al. conducted in Italy showed no significant correlation between the genetic changes in the $D B P$ gene with the onset or progression of the disease [42]. Our results revealed that haplotypes (1S-1S) were associated with vitamin D insufficiency. By contrast, the (1F-1F) haplotype had a significant protective association against insufficient levels of vitamin $\mathrm{D}$. SNPs at the $D B P$ gene are proven markers which account for most of the differences in vitamin $D$ concentration vary between ethnicities and populations [43]. Our results were consistent with earlier outcomes which showed that individuals carrying the (1F-1F) haplotypes had the highest serum levels of vitamin D compared with other genotypes [44, 45]. Interestingly, it was found that there is an association between low risk of MS and the existence of one copy at least of the rs7041 independently of vitamin D levels in most ethnicities [46]. These findings are inconsistent with previous study that detected tendency towards higher levels of vitamin D in MS patients carrying haplotypes 1F-1F [47]. Recently, it was shown the importance of assessing the status of vitamin D in patients [48] since different variations in the $D B P$ gene have a different response to the supplementation of

Table 4 Characterization of the $25(\mathrm{OH})$ vitamin D levels status in the study sample

\begin{tabular}{llll}
\hline Sample (no.) & Median, interquartile range of 25(OH) vitamin D level (range between parenthesis) & $95 \% C l$ for median & $p$ value \\
\hline MS (40) & $13.95,9.35$ to $18.05(8.0-26.0)$ & & $10.20-17.53$ \\
Controls (70) & $18.40,14.10$ to $27.0(8.70-38.5)$ & $0.0003^{*}$ \\
Sample (no.) & Severe deficiency (\%) & Insufficient (\%) & Sufficient (\%) \\
MS (40) & $11(27.5 \%)$ & $40(100 \%)$ & $0(0 \%)$ \\
Controls (70) & $5(7.1 \%)$ & $60(85.7 \%)$ & $10(14.3 \%)$
\end{tabular}

*Statistically significant associations $(p<0.05)$ 
vitamin D [49]. Thus, we recommend considering MS patients' genotypes and evaluate their vitamin status before introducing vitamin supplementation.

\section{Conclusions}

Genetic polymorphisms at the $D B P$ gene are risk factors in developing multiple sclerosis. The homozygous recessive genotype at $r 57041$ was mainly associated with vitamin D deficiency and with the risk of MS. This study is the first in Syria that studies the $D B P$ gene and polymorphisms consequence on MS patients; further studies are needed on large cohorts of patients and on other factors affecting MS.

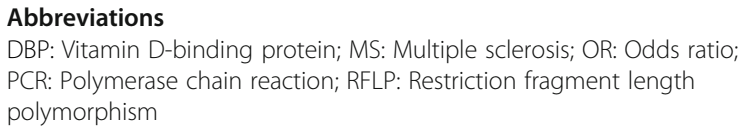

\section{Acknowledgements}

The authors wish to thank all the participants in this study and express gratitude towards workers at Al-Mouwasat and Ibn al Nafise hospitals for their collaborations.

\section{Authors' contributions}

$\mathrm{BH}$ : Study design, interview patient and healthy controls, and collect their approval of participation, collecting blood samples, performing molecular typing, analyzing data and results, revising the manuscript. GC: Study design, analyzing data and results, and writing and revising the manuscript. IK: Statistical analysis of the results, revising the manuscript. All authors read and approved the final manuscript.

\section{Funding}

This research was funded from university resources, grant no. 1938

\section{Availability of data and materials}

All data generated or analyzed during this study are included in this published article.

\section{Ethics approval and consent to participate}

This study has been approved by the ethical committee of Damascus University-Syria (no.1052/ 2018). A written informed consent was obtained from all participants.

\section{Consent for publication}

Not applicable.

\section{Competing interests}

The authors declare that they have no competing interests.

\section{Author details}

${ }^{1}$ Department of Biology, Faculty of Science, Damascus University, Damascus, Syria. ${ }^{2}$ Department of Fundamental Sciences, Faculty of Pharmacy, Arab International University, Damascus, Syria.

Received: 23 March 2020 Accepted: 18 June 2020

Published online: 10 August 2020

\section{References}

1. Palacios C, Gonzalez L (2014) Is vitamin D deficiency a major global public health problem? J Steroid Biochem Mol Biol 144:138-145 https://doi.org/10. 1016/j.jsbmb.2013.11.003

2. Holick MF (2007) Vitamin D deficiency. N Engl J Med 357(3):266-281. https://doi.org/10.1056/NEJMra070553

3. Bassil D, Rahme M, Hoteit M, Fuleihan GE (2013) Hypovitaminosis D in the Middle East and North Africa: prevalence, risk factors and impact on outcomes. Dermato-endocrinology. 5(2):274-298 https://doi.org/10.4161/ derm.25111

4. Munger KL, Levin LI, Hollis BW, Howard NS, Ascherio A (2006) Serum 25hydroxyvitamin D levels and risk of multiple sclerosis. Jama. 296(23):28322838. https://doi.org/10.1001/jama.296.23.2832

5. Lappe JM, Travers-Gustafson D, Davies KM, Recker RR, Heaney RP (2007) Vitamin D and calcium supplementation reduces cancer risk: results of a randomized trial. Am J Clin Nutr 85(6):1586-1591 https://doi.org/10.1093/ ajcn/85.6.1586

6. Autier P, Gandini S (2007) Vitamin D supplementation and total mortality: a meta-analysis of randomized controlled trials. Arch Intern Med 167(16): 1730-1737. https://doi.org/10.1001/archinte.167.16.1730

7. Borkar W, Devidayal, Verma S, Bhalla AK (2010) Low levels of vitamin D in North Indian children with newly diagnosed type 1 diabetes. Pediatr Diabetes 11(5):345-350 https://doi.org/10.1111/j.1399-5448.2009.00589.x

8. Arabi A, Khoueiry-Zgheib N, Awada Z, Mahfouz R, Al-Shaar L, Hoteit M, Rahme M, Baddoura R, Halabi G, Singh R, Fuleihan GE (2017) CYP2R1 polymorphisms are important modulators of circulating 25-hydroxyvitamin D levels in elderly females with vitamin insufficiency, but not of the response to vitamin D supplementation. Osteoporos Int 28(1):279-290 https://doi.org/10.1007/s00198-016-3713-5

9. Hoteit M, Al-Shaar L, Yazbeck C, Sleiman MB, Ghalayini T, Fuleihan GE (2014) Hypovitaminosis D in a sunny country: time trends, predictors, and implications for practice guidelines. Metabolism. 63(7):968-978 https://doi. org/10.1016/j.metabol.2014.04.009

10. Speeckaert M, Huang G, Delanghe JR, Taes YE (2006) Biological and clinical aspects of the vitamin D binding protein (Gc-globulin) and its polymorphism. Clin Chim Acta 372(1-2):33-42 https://doi.org/10.1016/j.cca. 2006.03.011

11. Bikle DD, Schwartz J (2019) Vitamin D binding protein, total and free vitamin D levels in different physiological and pathophysiological conditions. Front Endocrinol 10. https://doi.org/10.3389/fendo.2019.00317

12. Malik S, Fu L, Juras DJ, Karmali M, Wong BY, Gozdzik A, Cole DE (2013) Common variants of the vitamin $\mathrm{D}$ binding protein gene and adverse health outcomes. Crit Rev Clin Lab Sci 50(1):1-22 https://doi.org/10.3109/ 10408363.2012.750262

13. Jorde R, Schirmer H, Wilsgaard T, Mathiesen EB, Njølstad I, Løchen ML, Joakimsen RM, Grimnes G (2015) The DBP phenotype Gc-1f/Gc-1f is associated with reduced risk of cancer. The Tromsø study. PLoS One 10:5. https://doi.org/10.1371/journal.pone.0126359

14. Morgan S, Rowe R, Kirkham A, Hanks D (2016) Vitamin D binding protein isoforms and vitamin D levels in diabetes patients. American Society for Clinical Laboratory Science 29(3):152-157 https://doi.org/10.29074/ascls.29.3.152

15. Arnaud J, Constans J (1993) Affinity differences for vitamin D metabolites associated with the genetic isoforms of the human serum carrier protein (DBP). Hum Genet 92(2):183-188. https://doi.org/10.1007/bf00219689

16. Mokry LE, Ross S, Ahmad OS, Forgetta V, Smith GD, Leong A, Greenwood CM, Thanassoulis G, Richards JB. Vitamin D and risk of multiple sclerosis: a Mendelian randomization study. PLoS medicine. 2015 Aug;12(8). https://doi. org/10.1371/journal.pmed.1001866

17. Čierny D, Michalik J, Kantorová E, Kurča E, Lehotský J (2016) Genetic and biochemical factors related to the risk and disability progression in multiple sclerosis. Trending Topics in Multiple Sclerosis 8:1 https://doi.org/10.5772/ 63468

18. Niino M, Kikuchi S, Fukazawa T, Yabe I, Tashiro K (2002) No association of vitamin D-binding protein gene polymorphisms in Japanese patients with MS. J Neuroimmunol 127(1-2):177-179. https://doi.org/10.1016/s01655728(02)00099-1

19. Howard J, Trevick S, Younger DS (2016) Epidemiology of multiple sclerosis. Neurol Clin 34:919-939. https://doi.org/10.1016/j.ncl.2016.06.016

20. Browne P, Chandraratna D, Angood C, Tremlett H, Baker C, Taylor BV, Thompson AJ (2014) Atlas of multiple sclerosis 2013: a growing global problem with widespread inequity. Neurology. 83(11):1022-1024. https:// doi.org/10.1212/WNL.0000000000000768

21. García-Domínguez JM, Maurino J, Martínez-Ginés ML, Carmona O, Caminero AB, Medrano N, Ruíz-Beato E. Economic burden of multiple sclerosis in a population with low physical disability. BMC Public Health. 2019 Dec;19(1): 609. DOI: https://doi.org/10.1186/s12889-019-6907-x

22. World Health Organization 2017 https://www.worldlifeexpectancy.com/syriamultiple-sclerosis2/12/2020 
23. Holick MF, Binkley NC, Bischoff-Ferrari HA, Gordon CM, Hanley DA, Heaney RP, Murad MH, Weaver CM (2011) Evaluation, treatment, and prevention of vitamin D deficiency: an Endocrine Society clinical practice guideline. The Journal of Clinical Endocrinology \& Metabolism 96(7):1911-1930. https://doi. org/10.1210/jc.2011-0385

24. Inoue N, Watanabe M, Ishido N, Katsumata $Y$, Kagawa T, Hidaka Y, Iwatani $Y$ (2014) The functional polymorphisms of VDR, GC and CYP 2 R 1 are involved in the pathogenesis of autoimmune thyroid diseases. Clin Exp Immunol 178(2):262-269. https://doi.org/10.1111/cei.12420

25. Sawcer S, Hellenthal G, Pirinen M, Spencer CC, Patsopoulos NA, Moutsianas L, Dilthey A, Su Z, Freeman C, Hunt SE, Edkins S (2011) Genetic risk and a primary role for cell-mediated immune mechanisms in multiple sclerosis. Nature. 476(7359):214. https://doi.org/10.1038/nature10251

26. Sintzel MB, Rametta M, Reder AT (2018) Vitamin D and multiple sclerosis: a comprehensive review. Neurology and therapy 7(1):59-85. https://doi.org/ 10.1007/s40120-017-0086-4

27. Ascherio A, Munger $\mathrm{KL}$, White $\mathrm{R}$, Köchert $\mathrm{K}$, Simon $\mathrm{KC}$, Polman $\mathrm{CH}$, Freedman MS, Hartung HP, Miller DH, Montalbán X, Edan G (2014) Vitamin $D$ as an early predictor of multiple sclerosis activity and progression. JAMA neurology 71(3):306-314. https://doi.org/10.1001/jamaneurol.2013.5993

28. Shahbeigi S, Pakdaman H, Fereshtehnejad SM, Nikravesh E, Mirabi N, Jalilzadeh G. Vitamin $\mathrm{d} 3$ concentration correlates with the severity of multiple sclerosis. Int J Prev Med. 2013 May;4(5):585. PMID: 23930170; PMCID: PMC3733190.

29. Mazdeh M, Seifirad S, Kazemi N, Seifrabie MA, Dehghan A, Abbasi H (2013) Comparison of vitamin D3 serum levels in new diagnosed patients with multiple sclerosis versus their healthy relatives. Acta medica Iranica:289-292

30. Slavov GS, Manova MG, Trenova AG, Kostadinova II, Pavlov PI, Mateva NG, Zahariev ZI. 25 Hydroxyvitamin D and cytokines in multiple sclerosis. Folia Medica. 2016 Apr 1;57(3-4):200-6. DOl: https://doi.org/10.1515/folmed-20150039

31. Jeffery LE, Raza K, Hewison M (2016) Vitamin D in rheumatoid arthritis—towards clinical application. Nat Rev Rheumatol 12(4):201. https:// doi.org/10.1038/nrrheum.2015.140

32. Shoemaker TJ, Mowry EM (2018) A review of vitamin D supplementation as disease-modifying therapy. Mult Scler J 24(1):6-11. https://doi.org/10.1177/ 1352458517738131

33. Graves J, Barcellos L, Belman A, George M, Shao X, Quach H, Krupp L, Waubant E. Vitamin D genetic risk score is strongly associated with vitamin $\mathrm{D}$ levels and relapse rate in pediatric MS patients. InMULTIPLE SCLEROSIS JOURNAL 2016 Sep 1 (Vol. 22, pp. 419-420). 1 OLIVERS YARD, 55 CITY ROAD, LONDON EC1Y 1SP, ENGLAND: SAGE PUBLICATIONS LTD.

34. Yucel FE, Kamıslı O, Acar C, Sozen M, Tecellioğlu M, Ozcan C (2018) Analysis of vitamin $D$ receptor polymorphisms in patients with familial multiple sclerosis. Medical Archives 72(1):58. https://doi.org/10.5455/medarh.2017.72.58-61

35. Elkama A, Karahalil B (2018) Role of gene polymorphisms in vitamin D metabolism and in multiple sclerosis. Arch Ind Hyg Toxicol 69(1):25-31. https://doi.org/10.2478/aiht-2018-69-3065

36. Mesliniene S, Ramrattan L, Giddings S, Sheikh-Ali M (2013) Role of vitamin D in the onset, progression, and severity of multiple sclerosis. Endocr Pract 19(1):129-136. https://doi.org/10.4158/EP12152.RA

37. Maneechay W, Boonpipattanapong T, Kanngurn S, Puttawibul P, Geater SL, Sangkhathat S. Single nucleotide polymorphisms in the Gc gene for vitamin $\mathrm{D}$ binding protein in common cancers in Thailand. Asian Pac J Cancer Prev. 2015;16(8):3339-3344. PMID:25921141DOI:https://doi.org/10.7314/apjcp.2015. 16.8.3339

38. Tarighi S, Najafi M, Hossein-Nezhad A, Ghaedi H, Meshkani R, Moradi N, Fadaei R, Kazerouni F, Shanaki M (2017) Association between two common polymorphisms of vitamin D binding protein and the risk of coronary artery disease: a case-control study. Journal of medical biochemistry 36(4):349-357. https://doi.org/10.1515/jomb-2017-0015

39. Wang L, Song Y, Manson JE, Pilz S, März W, Michaëlsson K, Lundqvist A, Jassal SK, Barrett-Connor E, Zhang C, Eaton CB (2012) Circulating 25 hydroxy-vitamin $\mathrm{D}$ and risk of cardiovascular disease: a meta-analysis of prospective studies. Circulation: Cardiovascular Quality and Outcomes 5(6): 819-829. https://doi.org/10.1161/CIRCOUTCOMES.112.967604

40. Koplin JJ, Suaini NH, Vuillermin P, Ellis JA, Panjari M, Ponsonby AL, Peters RL, Matheson MC, Martino D, Dang T, Osborne NJ (2016) Polymorphisms affecting vitamin D-binding protein modify the relationship between serum vitamin D (25 [OH] D3) and food allergy. J Allergy Clin Immunol 137(2):500506 https://doi.org/10.1016/j.jaci.2015.05.051
41. Orton SM, Ramagopalan SV, Para AE, Lincoln MR, Handunnetthi L, Chao MJ, Morahan J, Morrison KM, Sadovnick AD, Ebers GC (2011) Vitamin D metabolic pathway genes and risk of multiple sclerosis in Canadians. J Neurol Sci 305(1-2):116-120. https://doi.org/10.1016/j.jns.2011.02.032

42. Agliardi C, Guerini FR, Zanzottera M, Bolognesi E, Costa AS, Clerici M (2017) Vitamin D-binding protein gene polymorphisms are not associated with MS risk in an Italian cohort. J Neuroimmunol 305:92-95. https://doi.org/10.1016/ j.jneuroim.2017.02.009

43. Powe CE, Evans MK, Wenger J, Zonderman AB, Berg AH, Nalls M, Tamez H, Zhang D, Bhan I, Karumanchi SA, Powe NR (2013) Vitamin D-binding protein and vitamin D status of black Americans and white Americans. N Engl J Med 369(21):1991-2000. https://doi.org/10.1056/NEJMoa1306357

44. Sollid ST, Hutchinson MY, Berg V, Fuskevåg OM, Figenschau Y, Thorsby PM, Jorde R (2016) Effects of vitamin D binding protein phenotypes and vitamin D supplementation on serum total $25(\mathrm{OH}) \mathrm{D}$ and directly measured free 25 (OH) D. Eur J Endocrinol 174(4):445. https://doi.org/10.1530/EJE-15-1089

45. Lauridsen AL, Vestergaard $P$, Nexo E. Mean serum concentration of vitamin D-binding protein (Gc globulin) is related to the Gc phenotype in women. Clin Chem 2001;47(4):753-756. PMID:11274031

46. Langer-Gould A, Lucas RM, Xiang AH, Wu J, Chen LH, Gonzales E, Haraszti S, Smith JB, Quach H, Barcellos LF (2018) Vitamin D-binding protein polymorphisms, 25-hydroxyvitamin D, sunshine and multiple sclerosis. Nutrients. 10(2):184 https://doi.org/10.3390/nu10020184

47. Agnello L, Scazzone C, Sasso BL, Bellia C, Bivona G, Realmuto S, Brighina F, Schillaci R, Ragonese P, Salemi G, Ciaccio M. VDBP, CYP27B1, and 25hydroxyvitamin $D$ gene polymorphism analyses in a group of Sicilian multiple sclerosis patients. Biochem Genet. 2017 Apr 1;55(2):183-192. DOI: https://doi.org/10.1007/s10528-016-9783-4

48. Gauzzi MC (2018) Vitamin D-binding protein and multiple sclerosis: Evidence, controversies, and needs. Mult Scler J 24(12):1526-1535 https:// doi.org/10.1177/1352458518792433

49. Al-Daghri NM, Mohammed AK, Bukhari I, Rikli M, Abdi S, Ansari MG, Sabico S, Hussain SD, Alenad A, Al-Saleh Y, Alokail MS (2019) Efficacy of vitamin D supplementation according to vitamin D-binding protein polymorphisms. Nutrition. 63:148-154 https://doi.org/10.1016/j.nut.2019.02.003

\section{Publisher's Note}

Springer Nature remains neutral with regard to jurisdictional claims in published maps and institutional affiliations.

\section{Submit your manuscript to a SpringerOpen ${ }^{\circ}$ journal and benefit from:}

- Convenient online submission

- Rigorous peer review

- Open access: articles freely available online

- High visibility within the field

- Retaining the copyright to your article

Submit your next manuscript at $>$ springeropen.com 